\title{
The Legal Structure Governing Philanthropy in the Philippines
}

\author{
Enrico Esteban B. Sabio* and Don Jaegal**
}

\begin{abstract}
Nongovernment organizations (NGOs) in the Philippines can be classified into several categories, depending on their goals. Some support government programs; others advocate for alternatives to government programs. A third group - philanthropic organizations - provide services that the government cannot provide sufficiently or at all. This study focuses on organizations in the third group and the impact of government interventions on them. The legal structure governing NGOs is described, and its effect on philanthropic organizations is analyzed. Factors that compelled the government to adopt laws and regulations affecting philanthropic organizations are discussed. Past and present trends in corporate philanthropy are briefly discussed. Findings indicate that existing laws and regulations have resulted in a social and administrative environment that encourages the private sector to be active in social welfare work. Incentives range from tax breaks to autonomy in governance and a significant role in public policy formulation.
\end{abstract}

Keywords: philanthropy, philanthropic organizations, social welfare

\section{INTRODUCTION}

Local and international trends indicate continuing innovations in governance, both in bureaucratic management and in ways of achieving the state's sociocultural, political, and economic goals. In both cases, national governments devolve some of their functions to local government units and others to the nongovernment sector. The partnership between private and public sectors continues to grow stronger, wider in scope,

\footnotetext{
* Enrico Esteban B. Sabio is Professor in the Department of Public Administration, Ramon Magsaysay Technological University, Philippines. His research interests include social welfare policy and public finance. E-mail: enrico_bsabio@yahoo.com.

** Don Jaegal, corresponding author, is Professor in the Department of Public Administration, Andong National University, Korea. His research interests include personnel administration, program evaluation, and quantitative methodology in public administration. E-mail: jaegal@ andong.ac.kr.
}

Manuscript received January 20, 2009; out for review March 6, 2009; review completed April 20, 2010; accepted April 21, 2010.

The Korean Journal of Policy Studies, Vol. 25, No. 1, 35-55 (2010)

(C) 2010 by the GSPA, Seoul National University 
and more exhaustive in depth. Its strength is manifested in the adoption of laws allowing the private sector to actively participate in policy formulation and implementation, its scope in the private sector's access to an increasing number of government functions, especially in service delivery, and its depth in government programs encouraging the private sector to get involved in social and scientific research and to contribute to agenda setting, identification of policy alternatives, and adoption of policy.

The private sector has also strengthened its role in social welfare work or philanthropy. Initiatives by the church, the private sector, and the government all contribute to nation building through humanitarian missions. These trends are also true in the Philippines, where the government has continued to engage the private sector's resources in nation building through social welfare work. In some cases, the government has tapped the private sector as its deputy to implement programs that it cannot execute alone. In other cases, the government accredits organizations as conduits and partners in achieving service delivery goals, and in still other instances, the philanthropic sector is encouraged to formulate and implement its own social welfare programs.

One of the biggest problems in relations between the government and nongovernmental organizations (NGOs) is the presence of legal and political obstacles organizations face to being officially recognized as nonprofit organizations (NPO)s. Considerable study has been devoted to the linkages between NPOs and governments in public problem-solving, focusing on the partnership between government and NPOs in service delivery, the role of advocacy groups in policymaking, and the contributions of NPOs to community building (Young 2007; Mendez 2001). In many cases, foundations remain in the background, working through their nonprofit grantees. The few instances in which foundations have been explicitly examined are little more than case studies of a single foundation and its efforts in the context of a particular initiative. Foundations have a range of strategic options vis-à-vis government in solving public problems beyond their traditional role of underwriting innovative programs and government taking the successes to scale (Prewitt 2006). ${ }^{1}$

1. Since the 1980s, philanthropic studies have emerged as a multidisciplinary field in the social sciences (Katz, 1999). However, a strong tendency in the past 30 years towards specialization among scientists in different disciplines has created the undesirable situation that scholars usually know little about the insights gathered in other disciplines. In addition, few of the insights from the academic literature have found their way in handbooks on fundraising. Previous reviews available to researchers in philanthropy are mostly confined to a specific discipline or a limited period of time. Sargeant and Woodliffe (2007) reviewed some literature regarding studies on charitable giving from a marketing perspective. Reviews in the field in of social psychology have dealt with helping behavior in general (Batson, 1998; Schroeder et al., 1995). Helping behavior is a very broad category of 
In recent years, substantial decline in government services, comprehensive bureaucratic reforms, and public policy innovations have redefined the cooperative and interactional relationships among the state, the market, and the NGO sector. NGOs' role in providing basic social services and public policy advocacy, once considered the domain of the government, has increased significantly. Notably, the NGO/philanthropic sector has expanded its niche from social work to the promotion of policy reform. NGOs have intensified their role as innovators for social transformation, facilitators of networking among multisectoral and cause-oriented constituencies, and overseers of the public and private sectors' performance of their mandates.

The increasing strength of social welfare NGOs has compelled the government to come up with measures to facilitate order in this field. In view of that, the main purpose of this study is to explicate some philanthropy-related issues, and it looks forward to finding that the legal structure governing the philanthropic sector in the Philippines has a positive impact on the growth and development of social welfare advocacy in the country. This study also explored the legal structure that constitutes the government's intervention in the philanthropic movement in the country.

\section{THEORETICAL VIEWS ON PHILANTHROPY}

\section{Philosophical Views on Philanthropy}

Private gifts for community purposes were not uncommon in the classical period, the most famous being Plato's gift of productive land as an endowment for his academy. Early Christians were commanded to give to the poor beyond their ability. Gifts of

actions, ranging from assisting a stranger in an emergency (Latane \& and Darley, 1970) to donating a piece of one's body to a relative (Schwarz \& and Howard, 1980). Charitable giving is also studied as an example of helping behavior in the social psychological literature. The subject gained popularity in mainstream social psychology towards the end of the 1970s, and continued to be studied in applied social psychology in the 1980s. However, charitable giving is likely to be different from many other forms of helping behavior. One crucial difference is that the recipient of charitable donations is usually absent from the context in which a donation is made, while the beneficiary is present in the helping situation investigated in most studies conducted in the 1960s and 1970s. The review differs from that by Piliavin and Charng (1990) in that it is not concerned primarily with the question to what extent to which prosocial behavior can be called altruistic. And for Lindahl and Conley (2002), fundraising is a field in need of a greater base of substantive, objective research rather than a casual acceptance of anecdotal evidence. 
property were common in the Christian era, and were used to establish monasteries, hospitals, colleges, and other semipublic institutions. ${ }^{2}$ Charity is what we give to alleviate the need, suffering, and sorrow of others, whether we know them or not, and what we give to prevent and correct social and environmental problems, and to improve life and living conditions for people and creatures we do not know and who have no claim on us, is philanthropy.

Modern philanthropy took shape in the years between about 1885 and 1915 as multimillionaires sought practical, socially useful ways of disposing of surplus wealth. Because of the immensity of their fortunes they had to think in wholesale terms: simple acts of kindness and generosity to widows and orphans or a traveler found wounded on a highway were not sufficient for their means (Bremner 1996). In a nutshell, the guiding principle of philanthropic work evolved from religious beliefs, to the realization of a secular duty to serve, to a businesslike approach in managing philanthropic affairs to ensure their sustainability, to a self-imposed mission to help, and to the adoption of more specific advocacies like social and scientific research in support of the government in its public service work.

\section{Political Views on Philanthropy}

Philanthropy is employed by the private sector as a vehicle to achieve social responsibility and a means to contribute to societal transformation. This may also be deemed as a mechanism supportive of or supplementary to the government's social welfare program, or better still, an embedded component of its initiative to facilitate change with minimal recourse to the government's resources. Similarly, philanthropy is a response to sociopathology as an urgent measure to meet pressing needs, or more importantly to deconstruct historical and contemporary social problems arising from systemic and structural dysfunctions toward constructing a better future. As such, philanthropy should be contextual to be relevant and justify its advocacy, time-bound to measure its efficacy, client-centered to define its purpose, integrated to avoid superfluous functions and overlapping endowments, and proactive to reduce the cost of disaster management. In other words, philanthropy as a response to a looming adversity

2. In his essay Wealth, Carnegie (1889) urged the proper administration of charitable groups so that the ties of brotherhood may still bind together the rich and poor in harmonious relationship; opposed indiscriminate charity as morally destructive; asserted that a man of wealth was to be the mere agent and trustee for his poorer brethren, doing for them better than they would or could do for themselves; and outlined his gospel of wealth at first through gifts of libraries to communities that promised to support them. 
is a fundamental raison d'etre for a humanitarian program.

For social transformation advocates, philanthropy can be an instrument to achieve social justice. Social justice philanthropy focuses on the root causes of social, economic, and environmental injustices. It strives to include the people who are marginalized by those injustices as decision-makers. It also aims to make the field of philanthropy more accessible and diverse, and to ensure that foundations are accountable, transparent, and responsive in their grant-making. Donors and foundations act as allies to social justice movements by contributing not only monetary resources but their time, knowledge, skills, and access. Social change philanthropy is also sometimes called social justice philanthropy, social movement philanthropy, and community-based philanthropy. ${ }^{3}$

\section{Social Activism and Philanthropy}

Social activists are skeptical about the genuineness of the philanthropic programs of the private sector. They believe that their donations are designed to avoid taxes on enormous profits, or worse, to cover up the permanent and immeasurable damage they inflict on the environment. Likewise, they suppose that these actions by big business are intended to subtly secure the favor of policy- and decision-makers. Social activists claim that corporate philanthropists prefer to part from a trickle of their wealth rather than earn the ire of decision-makers and power brokers, which may cost more.

According to Fleishman, Kohler, and Schindler (2007), philanthropists seek to intervene in the lives of others, or in the institutions that structure the lives of others, in order to improve their lives, create innovative solutions to problems, and create public goods. Philanthropy is therefore capable of harm as well as good. The notion that philanthropy can cause harm is perhaps at odds with popular conceptions about what philanthropy is and does, but even philanthropic practitioners recognize the potential for harm. Once we accept a modern conception of social justice, our first obligation must be to ensure that social institutions fulfill principles of justice. And then justice will

3. Governments generally support philanthropy because they believe that their resources and ability to provide services are insufficient. With society's expanding needs and demands, governments run short of resources. In most countries where philanthropic organizations abound, those who bequeath their resources to charity are provided with incentives such as tax credits and tax exemptions. However, some bureaucrats are apprehensive about the sincerity of some philanthropic activities, which they regard as likely calculated to earn the good graces of those in power, to acquire clout in decision making, or to find a way out of tax obligations. Worse, philanthropy may be seen as designed to acquire control of the government's power and policy structures. In short, philanthropy is viewed differently by bureaucrats, social transformation advocates, business leaders, and society in general. 
crowd out charity, both in theory and in practice. It is only by radically curtailing obligations of justice that earlier religious traditions were able to make significant space for charity.

\section{Strategic Philanthropy}

For years, an increasing number of studies have indicated the extent of philanthropic and charitable organizations' successes and the continuing increase in their significance. More importantly, this body of knowledge on private sector philanthropy seems to be optimistically responsive to critical comments regarding recent philanthropic practices, not only in the United States but also in Europe and Asia, both by those working in the sector and by their beneficiaries.

However, there are frustrations over a strong orientation toward transactive philanthropy, with a focus on the exchange of grant dollars for social good and not on the long-term value generated by those philanthropic dollars. This has heightened pressures on foundations to go beyond making grants to developing an approach that combines grant-making and non-grant-making activities that seek to increase effectiveness, focus, and strategic impact (Emerson and Bonini 2007). The main idea of this discourse is that the philanthropic sector by itself can facilitate transformational initiative rather than working in a supporting role to bring about social change for an improved quality of life in the community. Hence, it is imperative that philanthropical organizations engage in their work as strategically as possible.

\section{PHILANTHROPY IN THE PHILIPPINES}

\section{The Evolution of Philippine Corporate Philanthropy}

\section{Corporate Social Responsibility}

Corporate giving or philanthropy is defined as providing resources to intended beneficiaries (Luz 2000). Over time, this can develop a dole mentality and overdependence on corporations. To prevent this mindset, corporations have begun to treat philanthropy as a community or social investment, thereby reframing giving in terms of its returns to the community or society. Business community relations is the direct involvement of the company in community-based programs either by itself, in partnership with an NGO, community association, or local government, or in coalition with other businesses.

The partnership approach to development is common in the Philippines. There is a prevalent desire to pool corporate resources to achieve greater impact. Business and 
industry practices are addressed in codes of conduct in which best practices begin to be viewed as standards for operating businesses. These have become important selfregulating mechanisms and vehicles for corporations to buy into industry-wide practices. Corporate social responsibility emphasizes that consumers, employees, affected communities, and shareholders have a right to know about corporations and their business. It offers a paradigm that corporations are in effect public institutions whose survival depends on consumers and investors and that governance principles of accountability, transparency, and sustainability are key aspects of corporate social responsibility (Garilao 2002).

Corporate citizenship is not an option but an obligation to humanize the free market system and give it a measure of social responsibility. Helping the poor help themselves is the most effective, sustainable approach to reducing poverty, releasing human potential and achieving better socio-economic equity (Soriano 1995). Members of the corporate sector possess the resources and the management expertise and organization to respond to the challenge. They will likely benefit from the windfall of sustained economic growth if the gap between the rich and the poor is narrowed. It is their businesses that will make use of the country's larger consumer base and its greater disposable income. If the corporate sector is conscious of its social obligations and the benefits it would reap by addressing social issues, it can be a major force of development (Sycip 2000).

What stimulated the business sector towards this shift in perspective? The ensuing sections describe how the major sociopolitical developments within the last five decades pushed Philippine companies to realize innovative means of linking community interests to their own profit-orientation. ${ }^{4}$

\section{Profile of Corporate Giving}

For each recent decade, different trends in corporate giving can be identified.

The decade of donations (1960s): While the new business class was bent on gaining more wealth as quickly as possible, the economic imbalance from the land-based system which also characterized the society under capitalism became more apparent.

4. From the 1960s to the 1990s, corporate philanthropy underwent a process of transformation. The strong influence of the Roman Catholic Church on personal, state, and economic affairs paved the way for business altruism. The practice of corporate social responsibility emerged during the late 1960s as a business response to growing social unrest. Amidst activism in the 1960s and the 1970s, and concern for the environment in the 1980s and 1990s, corporate philanthropy took on a new meaning. From then on, businesses became proactively involved not only in economic affairs but in the sociopolitical affairs of the society, mainly through corporate social responsibility programs (Velasco 1996). 
This widening gap between the rich and poor is what defines the social inequity engendered by a profit-oriented economic system. Discontent grew at the government's inability to provide relief during economic downturns. This led progressive members of the business class to reassess their social responsibility in terms of genuine national development. They recognized that while they had been involved in various philanthropic works, these efforts had been seasonal, intermittent, fragmented, discontinuous, and disorganized. Thus they conceived the need for an organized, sustained, and professional mechanism for social welfare and humanitarian advocacy.

The decade of organization (1970s): The 1970s was characterized by socioeconomic uncertainty, political repression, and nationwide discontent that stirred the countryside, the factories, and most specially the youth, both in the universities and urban centers, and grew into a national protest movement that came to be known as the First Quarter Storm. Inspired by a business association in Venezuela, Dividendo Voluntario para la Communed, several business leaders organized Philippine Business for Social Progress (PBSP). Its mission was to develop a method that would attack national ills "in a way which parallels the vigor and industry with which private enterprise has tackled the challenge of economic development in the country (Derige et al. 2003). 5 The PBSP, BBC, and AF, all umbrella groups for organizations in the business sector, worked independently of each other notwithstanding their common goal of reinforcing corporate social responsibility.

The decade of involvement (1980s): This decade marked the coming of age of the PBSP, working at the forefront of the concerted effort to organize the activities of the different business establishments with charitable work, manifested by numerous requests for technical assistance in designing community programs. Attention is called to the part indicating philanthropy. Notice the 2 percent employment rate covered by the sector, the 5 percent payout rate, and the source of revenue, which does not include any funding from the government.

The decade of institutionalization (1990s): The business sector also developed the concept of corporate citizenship, which fostered the idea that since the corporation

5. The organization was financed by yearly pledges of 1 percent of gross profits by member companies. Of this funding, 60 percent was earmarked to finance development projects and the rest for the group's organizational programs. In its first decade, PBSP activities included (1) developing the capacity of partner NGOs through regional training centers, (2) building staff capabilities through intensive supervision and on-the-job training, (3) developing a focused grant-making program, and (4) maintaining the interest and commitment of the member companies. The organization also successfully opposed a move by the Philippine government in 1979 to impose a mandatory 1 percent corporate tax for social development under the management of a quasigovernmental body (Velasco, 1996). 
gains its financial strength and earns its profits from the people, it must reciprocate and fulfill its social responsibilities through programs that contribute to the people's welfare (Sycip 2000). This approach transcended short-term material assistance and sought to provide skills training and capacity building to foster a certain level of selfsufficiency and self-reliance among the beneficiaries. As a form of corporate citizenship, corporate giving is characterized by the voluntary transfer of resources to support various forms of development work. In the Philippine setting, companies often give as a result of active solicitation by institutions and individuals. ${ }^{6}$

The decade of continuous improvement (2000-2009): After three decades of immersion in social welfare work, the PBSP expanded its focus from service provision to a more systemic approach to poverty alleviation through the development of policy and social structures. This facilitated access to education and training for new skills, credit, and microfinance, which required the involvement of corporate citizens, the revival of the Center for Corporate Citizenship's research and test programs, and the constitution of a management structure leading to the company's improved, organized, and integrated implementation of its social responsibility. During this period, the PBSP introduced the Benchmarking Corporate Citizenship program and the Corporate Volunteer Program: Linking Worlds. Currently, PBSP is the largest grant-making business organization in the Philippines (PBSP 2002).

6. In 1992, the PBSP founded the Center for Corporate Citizenship in response to the following emerging challenges: (1) corporations concerned with long-term profitability are challenged to make equally long-term social investments in the society if local economies are to grow and the quality of life is to improve; and (2) in a world of limited resources, sustainable development is a challenge for corporations to be more critical of business practices and to redefine their relationship with the environment and people where they carry out their business (Velasco, 1996). In January 1993, the PBSP conducted a survey among 111 companies that implemented community relations programs (Velasco 1996). It yielded the following: (1) It is a practice upheld by companies regardless of size, sector or location. (2) In most cases, the CEOs were the driving force. This is a strength in that it receives high visibility in the corporation, but a weakness in that its motivations could be largely personality-driven. (3) Companies with plant-based operations or geographic considerations implement programs with a wider target base and broader concerns. (4) Though regarded as a management function, it provided limited human resources, with allotted resources originating mostly from the company budget. Finally, (5) issues confronting its practitioners included the need to translate social policies into coherent programs and to secure greater support from internal constituencies. If we assume that the average grant size by the philanthropic groups is just the 5 percent minimum payout rate of their endowment funds, the total assets of each organization might be considered quite substantial. 


\section{The Laws Governing Nongovernmental Philanthropic Organizations}

\section{The 1987 Philippine Constitution}

The 1987 Philippine Constitution recognizes the important role and significant contribution of NGOs and other NPOs in nation building, stating: "The state shall encourage non-governmental, community-based, or sectoral organizations that promote the welfare of the nation" (Section 23, Article II). Their roles and rights are enshrined as follows: "The state shall respect the role of independent people's organizations to enable the people to pursue and protect, within the democratic framework, their legitimate and collective interests and aspirations through peaceful and lawful means" (Section 15, Article XIII). It states further: "The right of the people and their organizations to effective and reasonable participation at all levels of social, political, and economic decision making shall not be abridged. The state shall by law, facilitate the establishment of adequate consultation mechanisms" (Section 16, Article XIII). The basic framework for the rise of the civil society sector in the Philippines is founded on the democratic right of the people to organize and form associations in order to pursue their legitimate collective interests and aspirations.

\section{The Local Government Code of the Philippines of 1991}

The Local Government Code, also known as Republic Act 7160, makes the following provisions:

Local government units shall promote the establishment and operation of people's and non-governmental organizations to become active partners in the pursuit of local autonomy (Section 34)

Local government units may enter into joint ventures and such other cooperative arrangements with people's and non-governmental organizations to engage in the delivery of certain basic services, capability-building and livelihood projects, and to develop local enterprises designed to improve productivity and income, diversify agriculture, spur rural industrialization, promote ecological balance, and enhance the economic and social well-being of the people (Section 35)

A local government unit may, through its local chief executive and with the concurrence of the sanggunian [council] concerned, provide assistance, financial or otherwise, to such people's and non-governmental organizations for economic, socially-oriented, environmental, or cultural projects to be implemented within its territorial jurisdiction (Section 36)

The real property of charitable institutions, churches, parsonages or convents 
appurtenant thereto, mosques, nonprofit or religious cemeteries and all lands, buildings, and improvements actually, directly, and exclusively used for religious, charitable or educational purposes shall be exempt from taxation. (Section 234b)

This code is the enabling law on the provisions of the constitution of people's empowerment, and the national government's efforts to devolve and decentralize some of its basic functions.

\section{The Corporation Code of the Philippines}

The corporation code (Batas Pambansa Bilang 68) states:

A non-stock corporation is one where no part of its income is distributable as dividends to its members, trustees, or officers, subject to the provisions of this Code on dissolution: Provided, That any profit which a non-stock corporation may obtain as an incident to its operations shall, whenever necessary or proper, be used for the furtherance of the purpose or purposes for which the corporation was organized, subject to the provisions of this Title. . . NPOs may not engage primarily in business or economic activities. They may engage only in those income-generating activities expressly allowed in their governing documents or necessary or incidental to the statutory objectives of the organization. Any profit generated from economic activities must be used in furtherance of the organization's objectives. (Section 87, Title X)

Non-stock corporations may be formed or organized for charitable, religious, educational, professional, cultural, fraternal, literary, scientific, social, civic service, or similar purposes, like trade, industry, agricultural and like chambers, or any combination thereof, subject to the special provisions of this Title governing particular classes of non-stock corporations. (Section 88, Title X)

This law sets the standards and provides the mechanisms for awarding non-stock and non-profit status, thereby providing organizations with a set of incentives.

\section{The National Internal Revenue Code of the Philippines}

Under this law, three provisions provide for tax exemptions for non-stock, charitable, and similarly oriented organizations. These items stipulate:

The following organizations shall not be taxed under this Title in respect to income received by them as such: (E) Non-stock corporation or association organized and operated exclusively for religious, charitable, scientific, athletic, or cultural purposes, or for the rehabilitation of veterans, no part of its net 
income or asset shall belong to or inures to the benefit of any member, organizer, officer or any specific person; $(G)$ Civic league or organization not organized for profit but operated exclusively for the promotion of social welfare; and $(\mathrm{H})$ A non-stock and nonprofit educational institution. (provisions $\mathrm{E}, \mathrm{G}$ and $\mathrm{H}$ of Section 30)

Section 87-D states: "All bequests, devises, legacies or transfers to social welfare, cultural and charitable institutions, no part of the net income of which insures to the benefit of any individual: Provided, however, That not more than 30 percent of the said bequests, devises, legacies or transfers shall be used by such institutions for administration purposes. Additionally, the philanthropic sector is exempt from real estate taxes (Section 80-d), a donor's tax under Section 94-a(3), and taxpayers may deduct contributions and gifts for income tax purposes up to 3 percent for corporations and 6 percent for individuals. ${ }^{7}$

\section{The Tariff and Customs Code of the Philippines}

This code deals with import duties. Many goods relevant to NPOs are exempted from customs duties, including books imported for use by educational institutions; articles donated to public or private institutions established solely for educational, scientific, cultural, charitable, health, relief, philanthropic or religious purposes, for free distribution among, or exclusive use of, the needy; and food, clothing, house-building and sanitary-construction materials, and medical, surgical, and other supplies for use in emergency relief work, when imported by or directly for the account of any victim, sufferer, refugee, survivor, or any other person affected thereby (Sec. 105-p, $r$ and s). This code provides for the duty-free status of organizations engaged in social work whose transactions involve importations of social work-related items.

7. Section 34(H) stipulates: "Contributions actually made within the taxable year are deductible in an amount not in excess of 10 percent for individuals and 5 percent for corporations, of the taxpayer's taxable income derived from trade, business, or profession. Corollarily, corporations, self-employed individuals and those engaged in the practice of their profession are allowed to deduct total annual contributions up to a percentage of their taxable income before contributions: 5 percent for corporations and 10 percent in the case of individuals. The contributions must be made to or for the use of the government of the Philippines or any of its agencies or any political subdivision thereof exclusively for public purposes, or to accredited domestic corporations or associations organized and operated exclusively for religious, charitable, scientific, youth and sports development, cultural, or educational purposes or for the rehabilitation of veterans, or to social welfare institutions or to non-government organizations." 


\section{The Philippine Securities and Exchange Reorganization Law}

A non-stock corporation may use the word "foundation" in its corporate name, provided that it meets the following requirements: (a) has initial capital of at least PHP $1,000,000$; (b) conducts its fund-raising campaigns in compliance with applicable laws and consistent with its submitted plan of operation; and (c) submits to the Securities and Exchange Commission in the Philippines a written statement of its willingness to allow the Commission to conduct an audit of its corporate books and records.

An SEC-registered foundation is required to annually file with the Commission an audited financial statement containing the source and amount of funds, the planned, ongoing, and accomplished program or activity, and the application of funds, as well as a certification from the local government office or the national social welfare and development or health agencies of the existence of the program or activity in the locality in which it exercises jurisdiction.

For this purpose, the term foundation refers to a non-stock, nonprofit corporation established for the purpose of extending grants or endowments to support its goals or raising funds to accomplish athletic, charitable, cultural, educational, literary, religious, scientific, social welfare, or other similar objectives (SEC 2006). A non-stock, nonprofit corporation is required to state in its incorporation papers that it is conducting microfinance operations pursuant to the Social Reform and Poverty Alleviation Act of 1997. This law specifies registration procedures for organizations seeking to acquire legal status in the country.

\section{Revenue Regulation No. 13-98}

This regulation, published in December 1998, specifies how an NPO may seek to become an accredited non-stock, nonprofit corporation or NGO. To qualify for accreditation, it must be organized for one or more of the following purposes: athletics, charity, culture, rehabilitation of veterans, religion, science, or social welfare. No part of the net income or assets of the organization may belong to or inure to the benefit of any member, organizer, officer, or other person (Section 1a). (The same prohibition is specified in the Tax Code.) Administrative expenses are limited to 30 percent of total expenses, and there are limitations on the distribution of assets upon the organization's dissolution (Section 1b).

Accredited NPOs are prohibited from undertaking a variety of transactions that would lead to direct or indirect private inurement: (1) lending any part of the organization's income or property without adequate consideration; (2) purchasing any security or property for more than adequate consideration; (3) selling any of the organization's property for less than adequate consideration; (4) diverting income of the organization 
to founders, directors, and persons closely related to them, using any part of its property, income, or seed capital for any purpose other than that for which the corporation was created or organized; and (5) engaging in any activity which is contrary to law, public order, or public policy (Section 10). ${ }^{8}$

\section{Distinctive Attributes of the Philanthropic Sector}

Philippine civil society is one of the most dynamic in the region, with a long history and as many as 500,000 members. Under the Aquino administration, the number of NGOs began to grow. The new-found freedom to organize and the influx of official development assistance were the key factors in addition to government accreditation and recognition. More importantly, the 1987 Constitution gave NGOs the power to represent the people's interests in consultations on local and national issues, including governance and policy-making (Quebral 2004).

Philippine NGOs have a number of distinctive attributes. First, political activism takes on a larger role for Filipino organizations than elsewhere. NGOs and NPOs played major roles in achieving Filipino independence from Spain and the United States and in toppling the authoritarian Marcos regime. Second, welfare activities emanating from the nongovernmental sector are clearly distinguished from religious or state-initiated welfare activities. Whereas the Spanish Catholic Church once dominated charitable and philanthropic activities, Filipino civil society has had a strong secular foundation since the American colonial administration. Third, NGOs have benefited from government administrations that, since the mid 1980s, have been generally supportive of civil society. This has resulted in one of the most well-developed and institutionalized civil society sectors in the developing world (ADB \& NGOC, 2007).

Table 1 summarizes the history of the PBSP. It started with 50 organizations whose

8. Further, the members of the board of trustees are prohibited from receiving compensation or remuneration except reasonable per diem payments because there is no such prohibition against remuneration of corporate officers. The regulation also states: "Corporations and individuals who derive income from a trade, business, or profession may deduct gifts, donations or contributions to accredited non-stock, non-profit corporations up to 5 percent of taxable income for corporate donors and 10 percent for individual donors" (Section 3a) and "Income refers to the donor's income derived from trade, business or profession as computed without the benefit of this deduction. Donations to accredited NGOs, by contrast, can be deducted in full" (Section 3b). In addition to income tax, donations and gifts to accredited NPOs are also exempt from the donor's tax, provided that not more than 30 percent of the donations and gifts for the taxable year are used by the accredited NPO for administrative expenses (Section 3c). 
Table 1. Philippine Business for Social Progress

\begin{tabular}{|c|c|c|}
\hline & $\begin{array}{l}\text { M embership } \\
\text { (Assets) }\end{array}$ & Focus of efforts \\
\hline $\begin{array}{l}\text { 1971-1975: } \\
\text { Building models } \\
\text { in short-term } \\
\text { projects }\end{array}$ & $\begin{array}{l}\text { 1970: } 50 \\
\text { 1973-74: } 150 \\
\text { 1975-76: } 124 \\
\text { (PHP 19.2 m) }\end{array}$ & $\begin{array}{l}\text { - Donations to poor communities } \\
\text { - Helping people help themselves } \\
\text { - Developmental approach: the application of business management } \\
\text { skills and hardheaded business sense to social development }\end{array}$ \\
\hline $\begin{array}{l}\text { 1976-1980: } \\
\text { From individual } \\
\text { to cooperative }\end{array}$ & $\begin{array}{l}170 \\
\text { (PHP 44.0 m) }\end{array}$ & $\begin{array}{l}\text { - Replicating successful pilot projects in more communities and } \\
\text { linking individual projects more closely } \\
\text { - Cooperative Small Economic Program: building up cooperatives } \\
\text { to become "little PBSPs" that can help local residents with } \\
\text { income-generating activities }\end{array}$ \\
\hline $\begin{array}{l}\text { 1981-1985: } \\
\text { Framew ork of } \\
\text { an integrated } \\
\text { area strategy }\end{array}$ & (PHP $33.0 \mathrm{~m})$ & $\begin{array}{l}\text { - Community organizing (livelihood, social credit, and basic social } \\
\text { services) } \\
\text { - Appropriate technology involving landless rural workers, } \\
\text { sustenance fisher folk, marginal upland farmers, urban poor, } \\
\text { and indigenous cultural communities. }\end{array}$ \\
\hline $\begin{array}{l}\text { 1986-1990: } \\
\text { Focusing efforts } \\
\text { on the poorest } \\
\text { provinces }\end{array}$ & $\begin{array}{l}\text { 1987-88: } 118 \\
\text { (PHP 214 m) }\end{array}$ & $\begin{array}{l}\text { - Consolidating efforts to } 15 \text { provinces in which at least } 40 \text { percent of } \\
\text { the families live below the poverty line, where PBSP had done some } \\
\text { work in the past, and where there were partner organizations } \\
\text { capable of implementing the program }\end{array}$ \\
\hline $\begin{array}{l}\text { 1991-1995: } \\
\text { Restrategizing } \\
\text { based on impact } \\
\text { of project }\end{array}$ & 174 & $\begin{array}{l}\text { - Redefining the scope of its strategy to work on the scale of } \\
\text { provinces but on the scale of impact areas-areas within a province } \\
\text { bordered by natural and resource boundaries }\end{array}$ \\
\hline $\begin{array}{l}\text { 1996-2000: } \\
\text { Developing the } \\
\text { workforce in } \\
\text { high-growth areas }\end{array}$ & 172 & $\begin{array}{l}\text { - Focusing assistance on the poverty groups affected by the shift } \\
\text { - Expanding the ARM program to include selected high-grow th areas } \\
\text { where the national government, business, and other sectors were } \\
\text { focusing their investment priorities }\end{array}$ \\
\hline $\begin{array}{l}\text { 2001-2005: } \\
\text { Putting corporate } \\
\text { citizenship in the } \\
\text { heart of business }\end{array}$ & 227 & $\begin{array}{l}\text { - Poverty alleviation } \\
\text { - Information technology } \\
\text { - Corporate citizenship } \\
\text { - Corporate social responsibility }\end{array}$ \\
\hline
\end{tabular}

Source: http://www.pbsp.org.ph, August 27, 2007; http://www.gdrc.org/icm/pbsp.html

programs ranged from alms giving to skills training. Over time, membership increased and programs expanded. Absolute membership numbers decreased from 1986 to 1990 , but this was a result of mergers of organizations with similar orientations or locations. With the restoration of political democracy and the emergence of the "period of legitimacy" in the late 1980s and early 1990s, NGOs were encouraged to be the government's conscience and watchdog in its campaign to curb corruption and 
improve the delivery of services. Legislation and government policies enshrined NGO rights and roles, and the government increasingly tapped NGOs as implementers and partners in its development programs. In the subsequent "period of institutionalization" (mid 1990s to the present), the government mainstreamed NGO representation in development planning, consulted with the NGOs sector in policy making and legislation, and legitimized its standing as an equal partner with the private sector (Abella and Dimalanta 2003).

Table 2 describes the Caucus of Development NGO Networks (CODE-NGO). In 1991, it was pioneered by ten national networks comprising almost 1,000 groups. Its main concern is the promotion of professionalism in the NGO sector. By 2005 it comprised seven national networks and four regional networks with more than 2,500 organizations. There has been a significant change in the focus of its efforts from social welfare advocacy to the establishment of linkages with foreign-based groups. Its initial membership was thirteen. Its main concerns include assistance to the needy and victims of natural disasters. Later years saw an increase in membership and expansion of its service area.

Table 2. Caucus of Development NGO Networks

\begin{tabular}{|c|c|c|}
\hline & Membership & Focus of efforts \\
\hline 1991 & $\begin{array}{l}10 \text { netw orks } \\
\text { with almost } \\
1,000 \text { member } \\
\text { organizations }\end{array}$ & $\begin{array}{l}\text { - Promoting professionalism } \\
\text { - Expanding the reach and increasing the effectiveness of } \\
\text { NGO/NPO work in the Philippines }\end{array}$ \\
\hline 2005 & $\begin{array}{l}7 \text { national } \\
\text { netw orks and } \\
4 \text { regional } \\
\text { netw orks with } \\
\text { more than } \\
2,500 \text { member } \\
\text { organizations }\end{array}$ & $\begin{array}{l}\text { - Building consensus on development issues and on the trajectory } \\
\text { of development work } \\
\text { - Establishing and upholding standards for development work } \\
\text { - Participating in forming public policy and engaging government at } \\
\text { various levels } \\
\text { - Promoting innovations in community development w ork and in } \\
\text { development finance } \\
\text { - Linking Filipino NGOs with the international development } \\
\text { community }\end{array}$ \\
\hline
\end{tabular}

Source: http://www.codengo.org, J anuary 25, 2008.

Table 3 summarizes the history of the League of Corporate Foundations. Its concerns evolved from simple issues such as donations to more complex issues such as policy advocacy, implementation, and governance. Absolute membership numbers decreased between the periods 1991-1995 and 1996-2000, but this was due to the mergers undertaken by some of the organizations either to strengthen their financial 
standing, or to operate in concert with similarly oriented organizations based in other parts of the country, or to implement their social work program in a more organized way.

Table 3. League of Corporate Foundations

\begin{tabular}{|c|c|c|}
\hline & Membership & Focus of efforts \\
\hline $\begin{array}{l}\text { 1991-1994: } \\
\text { Institution building }\end{array}$ & 13 & $\begin{array}{l}\text { - Fund raising } \\
\text { - Donations to social w elfare programs and government projects } \\
\text { - Relief operations in disaster areas }\end{array}$ \\
\hline $\begin{array}{l}\text { 1994-1996: } \\
\text { Period of } \\
\text { consolidation }\end{array}$ & 50 & $\begin{array}{l}\text { - Fund raising } \\
\text { - Donations to social welfare programs and government projects } \\
\text { - Networking with other similar organizations }\end{array}$ \\
\hline $\begin{array}{l}\text { 1996-1999: } \\
\text { Strengthening } \\
\text { the league }\end{array}$ & & $\begin{array}{l}\text { - Serving as bridge between civil society organizations and the } \\
\text { business community } \\
\text { - Engaging in mainstream programs like education, health and } \\
\text { governance } \\
\text { - M ainstreaming philanthropic advocacy work as well as into the } \\
\text { netw orks of civil society organizations } \\
\text { - Linking with bigger publics in crafting joint agendas and programs } \\
\text { for social development }\end{array}$ \\
\hline $\begin{array}{l}\text { 1999-2002: } \\
\text { Exploring new } \\
\text { horizons }\end{array}$ & $\begin{array}{l}57 \\
\text { ( anuary 27, } \\
\text { 2008) } \\
\text { (PHP } 4 \text { billion) }\end{array}$ & $\begin{array}{l}\text { - Benchmarking Project } \\
\text { - Celebration of the country's first Corporate Social Responsibility } \\
\text { W eek } \\
\text { - Serving as a capacity builder, data bank, consultant, advocate on } \\
\text { key issues, and bridge to grant opportunities } \\
\text { - Providing members a link to local, national, and international } \\
\text { foundations } \\
\text { - Strengthening the capacities of members }\end{array}$ \\
\hline
\end{tabular}

Source: Case Studies of Grant-maker Associations Around the World: The League of Corporate Foundations, Inc., http://www. wingsweb.org

On the whole, the government continues to consider NGOs as positive and enabling and a constructive and important influence in the development of a democratic Philippine society, and to believe that NGOs must be encouraged in their continuing growth as a legitimate, responsible, and self-regulating sector. In a bold move that has become a model of genuine partnership, the government has authorized the Philippine Council for NGO Certification (PCNC), an NGO set up and governed by the NGO community itself, to accredit NGOs applying for tax incentives through donee institution status, as long as these organizations meet the minimum standards for certification (Soledad 2002). As of October 22, 2007, the PCNC had certified at least 500 of the approximately 
6,000 eligible NGOs operating at the time of its launching (ngocoordinator@adb.org, 2007). Since 1986, the Philippines has developed and continues to evolve a constructive legal and policy framework for NPOs that has encouraged their proliferation in the region with almost 96,000 domestic and more than 150 foreign NPOs to date.

\section{The Evaluation of Philanthropic NGOs}

The legal mechanism needed to encourage philanthropy in the Philippines and to provide sustainable financing and staffing for NPOs is sufficiently in place. This study showed that the legal structure that evolved governing the $\mathrm{NGO}$ /philanthropic sector in the Philippines has had a positive impact on the growth and development of social welfare advocacy and encourages the growth and development of the sector. Before 1968, laws and regulations did not have a strong direct impact on the number of charitable organizations in the country, but they did reinforce the efforts of the church, individuals, and organizations to provide humanitarian services to society, and philanthropic organizations emerged sporadically during this period. In the mid 1960s, underdevelopment in the countryside and urban poverty placed the country in a state of social and political turmoil. Different sectors of Philippine society were drawn to action, channeling resources to address poverty and other social issues. The church set up the National Secretariat for Social Action in 1967. Finally, during this period, most social service efforts were short-term, characterized by a donor-recipient relationship, and rarely went beyond alms giving.

The period of 1968-1986 was characterized by social and NGO activism that developed rapidly during President Marcos's twenty years of authoritarian rule. The PNCCcertified philanthropic sector ballooned from 40 in 1967 to 140 in 1985. Like in the previous period, there was a gradual increase in the number of NGOs and philanthropic groups due to the prevailing sociopolitical and economic conditions of the country, which galvanized a collective response of the people to the social crisis. During this period, civic and service-oriented organizations progressed from simple alms-giving forms of social work to organizational capability building, networking, and policy advocacy for good governance. Relatively speaking, philanthropy has shifted from being the organizer's drive to wage social welfare advocacy into a national movement aiming to contribute to longer-term, people-centered, and community-based solutions to social problems.

Following the phenomenal and unprecedented political change that toppled the Marcos government in 1986, President Corazon Aquino moved to redemocratize Philippine society, starting with the abolition of the 1973 martial law constitution and replacing it with the 1987 Philippine Constitution. This was followed by the enact- 
ment of several progressive enabling laws, recognizing among other things the role of the private sector in community development and nation building through social work. This period marked a new frontier for the philanthropic sector. The NGO/NPO movement in general and the philanthropic sector in particular have come of age. Their status in Philippine society is enshrined in the constitution. Subsequently, NGOs and NPOs became more widely recognized for what they could do to affect national events. During this period, the networking endeavors of the different philanthropic organizations in the country culminated in the establishment of the nation's largest federated philanthropic groups, making philanthropic work national in scope, with a focus on proactive and people-centered solutions, and changing its focus from simple needs provision to policy making and advocacy for social change and for nation building through social work.

\section{CONCLUSIONS}

The philanthropic movement in the Philippines was established and sustained initially by the church and by private individuals and organizations, later followed by business groups. The government, on the other hand, focused on regulation and monitoring NGOs and NPOs, continued with its own mandated function to perform and deliver basic services, and has occasionally updated and upgraded its policy structure governing the NGO/NPO sector. Therefore, government interventions have had a positive impact on the NGO/philanthropic sector in the Philippines.

The study and advocacy of nonprofit law have not yet developed into a specific discipline of law in the Philippines, and the rules and regulations governing NPOs have yet to be codified into one law. At present, they are widely dispersed in various legislative enactments, executive initiatives, and court rulings. The legal structure governing the philanthropic sector in the Philippines has been very encouraging for its growth in terms of the number of organizations engaged in humanitarian work and the quality and scope of services they have delivered. The Constitution's recognition of the vitality of the role of the private sector in philanthropic work, and specific laws that provide incentives to existing and prospective philanthropic groups, are both an endorsement of the sector's past contributions to society and an invitation for a more active and effective participation in the future.

These observations have several implications. Organizations similar to those recognized as philanthropic organizations could create confusion as to what group is involved on a project. This could discredit legitimate NGOs or philanthropic groups if fly-by-night humanitarian groups carry out unlawful transactions. Overlapping of laws 
and regulations could create confusion as to what law applies to what situation; and if a controversy should arise, conflicting statutes could aggravate the problem. The existence and enforcement of similar laws by different agencies could also create problems for the government's coordination and monitoring of the social welfare programs of the philanthropic sector.

\section{REFERENCES}

Abella, C. T., and M. A. L. Dimalanta. 2003. NGOs as major actors in Philippine society. Paper presented at the APPC conference, Philippines, September.

ADB's NGO and Civil Society Center. 2007.ngocoordinator@adb.org, December.

Batson, C. D. 1998. Altruism and prosocial behavior. In D. T. Gilbert (ed.), Handbook of social psychology. New York: Random House.

Bremner, R. H. 1996. Giving: Charity and philanthropy in history. New Brunswick, NJ: Transaction Publishers.

Carnegie, A. 1889. Wealth. North American Review 148(391): 653-64.

Emerson, J., and S. Bonini. 2007. Blended value map: Tracking the intersects and opportunities of economic, social and environmental value creation. Corporate Philanthropy Institute: A guide for practitioners. North Carolina.

Fleishman, J., J. S. Kohler, and S. Schindler. 2007. Foundation-government relations in public problem solving: The unexamined link in collaborative governance. In Casebook for foundations: A great American secret. New York: Public Affairs.

Garilao, E. 2002. The growing importance of corporate social responsibility in Asia. Speech delivered during the Asian Forum on Corporate Social Responsibility at the 5th Hitachi Young Leaders Initiative, Singapore, July 29-August 2. http://www.answers.com/topic/philanthropy 2008

Katz, S. N. 1999. Where did the serious study of philanthropy come from, anyway? Nonprofit and Voluntary Sector Quarterly 8: 74-82.

Latané, B., and J. M. Darley. 1970. The unresponsive bystander: Why doesn't he help? New York: Meredith.

Lindahl, W. E., and A. T. Conley. 2002. Literature review: Philanthropic fundraising. Nonprofit Management and Leadership 13: 91-112.

Luz, J. M. 2000. Corporate social responsibility in the global community: A view from the ground. Building Partnerships for Development. Philippines.

Mendez, J. L. 2001. Civil organizations in Mexico: Recent evolutions and current prospects. In H. Anheier and J. Kendall (ed.), Third sector policy at the crossroads. Routledge. 
PBSP (Philippine Business for Social Progress). 2002. Annual Report. Manila: PBSP. Piliavin, J. A., and H.-W. Charng. 1990. Altruism: A review of recent theory and research. Annual Review of Sociology 16: 27-65.

Prewitt, K. 2006. Foundations. In W. Powell and R. Steinberg (ed.), The non-profit sector: A research handbook, 2nd ed. New Haven, CT: Yale University Press.

Quebral, M. 2004. http://www.allianceforjustice.org/index.hmtl.

Sargeant, A., and L. Woodliffe 2007. Individual giving behaviour: A multi-disciplinary review. In A. Sargeant and W. Wymer (ed.), The non-profit marketing companion. London: Routledge.

Schroeder, D. A., J. F. Dovidio, L. A. Penner, and J. A. Piliavin. 1995. The social psychology of helping and altruism. New York: McGraw-Hill.

Schwartz, S. H., and J. A. Howard. 1980. Explanations of the moderating effect of responsibility denial on the personal norm-behavior relationship. Social Psychology Quarterly 43: 441-46.

SEC (Securities and Exchange Commission). 2006. Memorandum circular no. 8. Manila: SEC.

Soledad, F. 2002. Accountability as a sector: The PCNC Experience. Paper presented at the 2002 Southeast Asia Regional Conference on Civil Society Resource Organizations, Pattaya, Thailand, February 18-20.

Soriano, A., III. 1995. A quarter of a century in social development. Manila: Philippine Business for Social Progress.

Sycip, W. 2000. Our legacy. Manila: Philippine Business for Social Progress.

Velasco, M. G. T. 1996a. Corporate philanthropy in Asia: The Philippine case. 1996b. Overview of organized philanthropy in the Philippines. In T. Yamamoto (ed.), Emerging civil society in the Asia-Pacific community. Singapore: Institute for Southeast Asian Studies and Asia Pacific Philanthropy Consortium.

Young, D., 2007. Complementary, supplementary, or adversarial? In E. T. Boris and C. E. Steuerle (ed.), Nonprofits \& government: Collaboration \& conflict (pp. 3780). Washington, DC: Urban Institute Press, 2006. 